\title{
Solitary Confinement, Prisoner Litigation, and the Possibility of a Prison Abolitionist Lawyering Ethic
}

Debra Parkes

\begin{abstract}
This paper considers the role that litigation might play in ending the human rights crisis of solitary confinement in Canada while also examining the relationship of prisoner rights litigation to broader, anti-carceral social movements. The paper proceeds in four parts. The first section provides a brief overview of the widespread use of solitary confinement in Canada's federal prisons and in provincial and territorial jails. Next, current litigation seeking an end to solitary confinement in the federal prisons system is located in the context of a long history of prisoner rights litigation in both the US and Canada. The third section considers the possibilities and challenges of pursuing prisoner rights litigation with broader critiques of the carceral state in mind. The paper ends with examples of anti-carceral lawyering efforts and identifies some elements of a prison abolitionist lawyering ethic.
\end{abstract}

Keywords: solitary confinement, prisoners' rights, prison abolition, social justice lawyering, human rights

\section{Résumé}

Cet article porte sur le rôle que pourrait jouer le contentieux judiciaire pour mettre fin à la crise des droits de la personne liée à l'isolement cellulaire au Canada. De plus, il se penche sur la relation entre les litiges ayant trait aux droits des prisonniers et les mouvements sociaux anti-carcéraux. L'article est divisé en quatre parties. La première présente un bref aperçu du recours très répandu à l'isolement dans les prisons canadiennes fédérales, provinciales et territoriales. Ensuite, il situe l'état actuel du contentieux judiciaire visant à mettre fin à l'isolement dans le système des prisons fédérales dans le contexte de la longue histoire des litiges liés aux droits des prisonniers aux États-Unis et au Canada. La troisième partie porte sur les possibilités et les défis des litiges relatifs aux droits des prisonniers et s'inscrit dans une critique plus globale sur l'état carcéral. Enfin, l'article se termine sur des exemples d'efforts déployés en matière d'exercice du droit anti-carcéral et met en exergue certains éléments d'une éthique de la pratique du droit qui serait abolitionniste.

Mots clés : isolement, droits des prisonniers, abolition des prisons, droit et justice sociale, droits de la personne 
The widespread and prolonged use of solitary confinement, or segregation, as it is called in Canadian prisons, is a pressing human rights issue with gendered and racialized dimensions. Women may be disproportionately put in "the hole" for relatively minor infractions and for mental health reasons (i.e., ostensibly for their own safety), and Indigenous women and men are vastly over-represented among those in solitary. Periodically the public catches glimpses of the inhumanity of solitary confinement through reports of deaths in custody, including Ashley Smith, who died with a ligature around her neck in a segregation cell while correctional officers watched. Numerous reports have called for independent adjudication of decisions to place or maintain prisoners in solitary, hard time limits on its use, and, more recently, abolition of the practice altogether. Yet regular and prolonged solitary confinement remains a management tool in prisons across the country.

This paper considers the role that litigation might play in ending this human rights crisis, as well as the relationship of prisoner rights litigation to broader, anticarceral social movements. There have been some limited successes in prisoners' rights litigation in Canada, including a handful of cases in which particular placements in solitary have been found to violate the Charter. However, systemic claims that engage issues of institutional security face numerous challenges including a tendency of judges to defer to correctional and legislative decisions in the prison context, as well as a fundamental acceptance of the logic of punishment and deprivation through incarceration. The paper proceeds in four parts. The first section provides a brief overview of the widespread use of solitary confinement in Canada's federal prisons and in provincial and territorial jails. Next, current litigation seeking an end to solitary confinement in the federal prisons system is located in the context of a long history of prisoner rights litigation in both the United States and Canada. The third section considers the possibilities and challenges of pursuing prisoner rights litigation with broader critiques of the carceral state in mind, and the paper ends with some thoughts on the potential for a prison abolitionist ethic to infuse lawyering efforts.

\section{Solitary Confinement in Canada}

Awareness is rising in Canada and around the world that the practice of isolating human beings in small prison cells with little human contact is harmful, inhumane, and amounts to torture. In October 2016, Canadians learned about the more than four years that Adam Capay spent in a Plexiglas-lined, permanently-lit solitary confinement cell in a Northern Ontario jail. Capay is a twenty-three-yearold Indigenous man who is awaiting trial for murder in the Thunder Bay jail and whose story prompted newspaper editorials decrying the inhumanity of his prolonged detention in particularly brutal conditions of solitary confinement. ${ }^{1}$ The conditions of confinement experienced by Capay and women such as Ashley Smith and Terry Baker, ${ }^{2}$ who both died in segregation cells at the federal Grand

1 See, e.g., Editorial, "Ontario's sickening mistreatment of Adam Capay," The Globe and Mail, 24 October 2016; and Editorial, "Release Adam Capay from solitary confinement," The Toronto Star, 25 October 2016.

2 Sara Mojtehedzadeh, "Woman who died in prison complained of being tied to her bed, advocates say," The Toronto Star, 7 July 2016. 
Valley Institution for Women, are recognized as torture under international human rights law. In late 2015, the United Nations General Assembly unanimously adopted a revised version of the Standard Minimum Rules for the Treatment of Prisoners, ${ }^{3}$ known as the Mandela Rules after the late President of South Africa, who was incarcerated for twenty-seven years, much of that in solitary confinement, for his leadership of the anti-Apartheid movement.

The Mandela Rules prohibit the imposition of indefinite or prolonged solitary confinement, and they prohibit it outright for women, children, and people with mental and physical disabilities whose conditions would be exacerbated by it. ${ }^{4}$ The Rules define solitary confinement as "the confinement of prisoners for 22 hours or more a day without meaningful human contact" and prolonged solitary confinement as "solitary confinement for a time period in excess of 15 consecutive days." In its statement of defence to a recently-filed lawsuit challenging the constitutional validity of administrative segregation in federal prisons, the Attorney General of Canada claims that its use of "administrative segregation is different from and not analogous to the concept of solitary confinement referred to in many foreign jurisdictions and should not be confused with it." In fact, as the Mandela Rules definition makes clear, solitary confinement is an umbrella term for the lived reality of isolation in a prison cell for twenty-two to twenty-four hours, a reality which is called by many different names in places of detention around the world. The fifteen-day marker for prolonged segregation originated in the Report of the Special Rapporteur on the Convention Against Torture in 2011, ${ }^{7}$ which was, in turn, based on the substantial evidence of mental and physical harm found in studies of people who experienced solitary for anything other than very short periods. ${ }^{8}$ Few, if any, correctional authorities call their use of solitary confinement by that name. It is the nature of the isolating conditions that matters, not the name or policy surrounding those conditions. Prisoners in administrative segregation and other forms of isolation in Canada are experiencing solitary confinement and all its attendant harms.

In Canada's federal prison system, which incarcerates people serving sentences of two years or more, there were 8,309 placements in administrative (non-disciplinary) segregation in the 2014-2015 fiscal year. ${ }^{9}$ These placements

UN-Doc A/Res/70/175, 17 December 2015 (“Mandela Rules”).

Mandela Rules, Rule 45(2).

Mandela Rules, Rule 44.

On file with author.

Special Rapporteur of the Human Rights Council on torture and other cruel, inhuman or degrading treatment or punishment, Juan E. Méndez, Interim report of the Special Rapporteur of the Human Rights Council on torture and other cruel, inhuman or degrading treatment or punishment, GA Res 65/205, UNGAOR, $66^{\text {th }}$ Sess, UN Doc. A/66/268 (5 August 2011).

8 See, e.g., Craig Haney, "Mental Health Issues in Long-Term Solitary and 'Supermax' Confinement," Journal of Crime and Delinquency 49 (2003): 124; Stuart Grassian, "Psychiatric Effects of Solitary Confinement," Journal of Law \& Policy 22 (2006): 235; and Peter Scharff Smith, "The Effects of Solitary Confinement on Prison Inmates: A Brief History and Review of the Literature," Crime \& Justice 34 (2006): 441.

9 Office of the Correctional Investigator, Administrative Segregation in Federal Corrections: 10 Year Trends, 28 May 2015, 4 ["10 Year Trends"], online: http://www.oci-bec.gc.ca/cnt/rpt/pdf/oth-aut/ oth-aut20150528-eng.pdf. 
involved 4,999 prisoners as some individuals had more than one period of incarceration in segregation. The average length of those placements was twenty-seven days, but many prisoners spent much longer periods in segregation. As noted by the Correctional Investigator (the federal prison ombudsperson), administrative segregation "is so overused [as a management tool] that nearly half (48\%) of the current inmate population has experienced segregation at least once during their present sentence."

Comparatively little is known about the numbers of people incarcerated in provincial and territorial segregation cells, where external oversight is very limited and records are often not kept or not released to the public. ${ }^{11}$ This is a serious gap in accountability because, on any given day, the vast majority of people incarcerated in Canada are in provincial or territorial jails, either awaiting trial or serving sentences of less than two years. ${ }^{12}$ Occasional news stories such as those about Adam Capay, together with the accounts of prisoner advocates, provide troubling anecdotal evidence of the widespread, prolonged, and inhumane use of solitary confinement in provincial and territorial jails. These correctional systems are even more opaque and unaccountable than the federal Correctional Service of Canada, although pressure is mounting for correctional accountability. Recently, the Ontario government has started to collect and release more data on its use of segregation due to pressure from the Ontario Human Rights Commission. ${ }^{13}$ An access to information request in Quebec produced some basic data about the number of prisoners held in segregation for disciplinary and administrative reasons, revealing an upward trend in those placements. ${ }^{14}$ Research on segregation placements in a provincial women's jail in Manitoba, obtained through costly freedom of information requests, ${ }^{15}$ revealed an unaccountable-in many cases,

10 Office of the Correctional Investigator, Annual Report of the Office of the Correctional Investigator 2014-2015, 26 June 2015, at 26, online: http://www.oci-bec.gc.ca/cnt/rpt/pdf/annrpt/annrpt20142015eng.pdf.

11 Patrick White, "Solitary confinement reform hindered by gaps in prison statistics," The Globe and Mail, 28 March 2016.

12 In 2014/2015, there were 39,623 adults incarcerated in Canada on an average day, with 24,455 of those adults in provincial/territorial custody and 15,168 in federal custody. Julie Reitano, "Adult correctional statistics in Canada, 2014/2015," Juristat 85-002-X (26 March 2016).

13 Amy Dempsey, "Data reveal 'shocking' numbers of Ontario inmates in solitary," The Toronto Star, 1 March 2016.

14 Annabelle Blais, "De plus en plus de détenus envoyés au "trou»" Actualité, 20 April 2016, online: http://www.journaldemontreal.com/2016/04/20/de-plus-en-plus-de-detenus-envoyes-au-trou; Response of the Ministry of Public Safety to request \#116344 (6 April 2016), online: http://www. securitepublique.gouv.qc.ca/fileadmin/Documents/ministere/diffusion/documents_transmis_ acces/2016/116344.pdf.

15 In response to my request under the Freedom of Information and Protection of Privacy Act, C.C.S.M. c. F175, for the 2009 records of the use of segregation in the province's primary women's and men's jails, the Manitoba government stated that the records did not exist in any producible form as the only notations were in individual inmate files. Following my appeal to the Manitoba Ombudsman, the government required me to pay over $\$ 5,000$ in fees for the production of an excel spreadsheet, itemizing the 167 documented segregation placements in the women's jail for that year. My request for the same records for the men's jail was refused on the basis that the fees would be prohibitive (there are roughly ten times more men than women in prison in Manitoba so the inmate files would be voluminous). The possibilities and challenges of using access to information processes for social justice research are discussed in Jamie Brownlee and Kevin Walby, eds., Access to Information and Social Justice: Critical Research Strategies for Journalists, Scholars, and Activists (Winnipeg: Arbeiter Ring Press, 2015). See also Mike Larsen and Kevin Walby, Brokering Access: Power, Politics and the Freedom of Information Process in Canada (Vancouver: UBC Press, 2013). 
lawless-use of solitary confinement, including twenty-seven percent of documented placements in administrative (non-disciplinary) segregation listed as for "overflow" and thirty-two percent for no documented reason at all. ${ }^{16}$

The practice of solitary confinement in Canada is consistent with its discredited but widespread use as a management tool in correctional systems around the world. ${ }^{17}$ Peter Scharff Smith has described how "a belief in the ability to rehabilitate criminals through the use of isolation regimes became a cornerstone [of the] modern prison system" that developed in the United States in the early nineteenth century and later that same century in Europe. ${ }^{18}$ Canadian prisons have been part of this global phenomenon of proliferating and normalized solitary confinement. However, there are increasing calls to radically limit or abolish the practice, coming in the media, ${ }^{19}$ from civil society groups, ${ }^{20}$ and in the courts. The next section examines efforts to reign in the devastating practice of solitary confinement through litigation in the United States and Canada.

\section{A Short History of Litigation Against Solitary Confinement}

\subsection{United States}

The harms of solitary confinement have been evident and its legality questioned from the earliest days of its use in the United States. In a decision released in 1890, the US Supreme Court said this about the practice of solitary confinement in a Colorado prison, albeit in non-binding obiter dicta: "A considerable number of the prisoners fell, after even a short confinement, into a semi-fatuous condition, from which it was next to impossible to arouse them, and others became violently insane; others still, committed suicide; while those who stood the ordeal better were not generally reformed, and in most cases did not recover sufficient mental activity to be of any subsequent service to the community." ${ }^{21}$

The Court found these conditions of confinement to be "an additional punishment of the most important and painful character" in violation of the Eighth Amendment prohibition against cruel and usual punishment. The Court ordered Medley, who had been convicted of murder and sentenced to death, released from prison despite his conviction. However, they stopped short of finding that solitary confinement per se violated the Constitution. ${ }^{22}$

Since Medley, there has been much litigation about solitary confinement in the United States. However, despite some limits being imposed on particularly harsh

16 Debra Parkes, "Ending the Isolation: An Introduction to the Special Volume on Human Rights and Solitary Confinement," Canadian Journal of Human Rights 4, no. 1 (2015): vii, viii.

17 Special Rapporteur of the Human Rights Council, 2.

18 Peter Scharff Smith, "Solitary Confinement-History, Practice, and Human Rights Standards," Prison Service Journal 181 (2009): 3.

19 See e.g., Editorial, "Solitary confinement should be rare," The Globe and Mail, 19 January 2015.

20 See e.g., West Coast Prison Justice Society, Solitary: A Case for Abolition, November 2016. The Canadian Association of Elizabeth Fry Societies has long called for the abolition of segregation for women prisoners: Canadian Association of Elizabeth Fry Societies, "A push to end segregation," 5 November 2016, online: http://www.caefs.ca/category/news/.

21 In re Medley, 134 US 160 at 168 (1890).

22 Ibid. 
conditions or regimes, ${ }^{23}$ the practice persists, with over 80,000 people in conditions of solitary confinement in American prisons on any given day. ${ }^{24}$ As will be further discussed below, the American experience with prisoner rights litigation against solitary confinement is a cautionary tale for Canadian activists. Keramet Reiter has documented some of the successes of US prisoner litigation in the 1970s, in which courts in a number of states decried particularly horrific conditions in solitary (such as dark, filthy cells where prisoners were denied food or any human contact for days and weeks) and declared those conditions cruel and unusual in violation of the Eighth Amendment. ${ }^{25}$ In response, states built new solitary confinement units that met the minimum standards for space, light, and other amenities required by courts. ${ }^{26}$ No court ordered the total elimination of solitary confinement. Instead, the litigation arguably contributed to legitimizing the pervasive and prolonged use of solitary confinement, provided certain standards were met.

American prisoners are still litigating in an attempt to reign in the prolonged, indefinite imposition of solitary confinement, and they are achieving some traction. In 2015, prisoners and their advocates in California achieved an historic settlement in a class action brought by men serving prolonged periods-many for decades - in solitary confinement in the Pelican Bay Security Handling Unit or SHU. ${ }^{27}$ The extreme nature of the SHU regime was described by the men's lawyers:

At Pelican Bay State Prison alone, more than 500 prisoners had been held in the SHU for over 10 years, and 78 prisoners had been there for more than 20 years. They were warehoused in cramped, windowless concrete cells for almost 24 hours a day with no phone calls, infrequent visits through plexiglass preventing physical contact, meager rehabilitative opportunities, and no opportunity for normal social interaction with other prisoners. Their indefinite and prolonged confinement in this torturous isolation was based not on any actual misconduct but on vague and tenuous allegations of affiliation with a gang. Prisoners were routinely placed in prolonged solitary confinement for simply appearing on a list of gang members found in another prisoner's cell, or possessing allegedly gang-related artwork and tattoos. ${ }^{28}$

23 Keramet Reiter, "The Most Restrictive Alternative: A Litigation History of Solitary Confinement in U.S. Prisons, 1960-2006," Studies in Law, Politics and Society 57 (2012): 69.

24 David Fathi, “The United States: Turning the Corner on Solitary Confinement," Canadian Journal of Human Rights 4 (2015): 168, citing Reassessing Solitary Confinement: The Human Rights, Fiscal, and Public Safety Consequences: Hearing Before the Senate Committee on the Judiciary, Subcommittee on the Constitution, Civil Rights and Human Rights, 112th Cong (Washington, DC: Homeland Security Digital Library, 2012). Reiter, "Most Restrictive."

Ibid.

27 Keramet Reiter, "Unsettling Solitary Confinement in California’s Prisons," Social Justice blog, 28 September 2015, online: http://www.socialjusticejournal.org/unsettling-solitary-confinementin-californias-prisons/.

28 Center for Constitutional Rights, "Summary of Ashker v. Governor of California Settlement Terms," online: https://ccrjustice.org/sites/default/files/attach/2015/08/2015-09-01-Ashker-settlementsummary.pdf. 
Lisa Guenther has described the extent to which prisoner activism, the hunger strikes, and a solidarity movement on the outside were vital parts of the struggle. ${ }^{29}$ In settling Ashker v. Governor of California, the state agreed to a new, five-year cap on the amount of time a prisoner could spend in solitary confinement in the SHU and scrapped the "gang validation" policy which had been a primary basis for placement in the SHU. ${ }^{30}$ This is a significant victory in the California context, and one that is rightly celebrated, but prolonged solitary confinement and a punitive regime of mass incarceration remain entrenched in correctional law and policy.

\subsection{Canada}

The story of Canadian prisoners challenging solitary confinement in the courts begins in British Columbia in the early 1970s. Michael Jackson, a lawyer and law professor at the University of British Columbia represented eight men imprisoned in the BC Penitentiary's brutal Special Correction Unit (SCU) in a Federal Court challenge to their conditions of confinement. ${ }^{31}$ The Court heard evidence of the horrific experiences of prisoners in solitary. Jackson describes some of that evidence:

Jack McCann gave evidence that in 1967 on three successive days other prisoners slashed themselves. He was given the job of cleaning up the blood in their cells. McCann "begged and pleaded to be taken out of solitary." Yet another prisoner slashed himself. McCann could take no more and he set himself on fire in his cell. He described to the court what he saw as the flames engulfed him: "I remember watching the space beneath the door get bigger. I thought I could crawl beneath it and be free.... I wanted to get out-I don't care if I die, I never want to go back to that position again."32

In a ground-breaking decision released in 1976, Justice Heald issued a declaration that imprisonment of these men in solitary confinement amounted to cruel and unusual punishment, contrary to s. 2(b) of the Canadian Bill of Rights. ${ }^{33}$ By the time of the decision, all of the plaintiff prisoners were no longer in the SCU; nevertheless, the finding that their conditions of solitary confinement were illegal marked the beginning of a modern prisoner rights movement in Canada. Jackson has chronicled the extent to which federal correctional authorities have subsequently resisted at every turn calls in numerous reports and commissions of inquiry to limit the use of solitary confinement in Canadian prisons and to subject its use to external, independent oversight. ${ }^{34}$

Fast forward forty years to late 2016 and another group of lawyers in Vancouver is gearing up for a trial in BC Supreme Court. They will argue that the legislative

\footnotetext{
29 Lisa Guenther, "Political Action at the End of the World: Hannah Arendt and the California Prison Hunger Strikes," Canadian Journal of Human Rights 4 (2015): 33.

30 Center for Constitutional Rights.

31 McCann v. The Queen, [1976] 1 FC 570. See Michael Jackson, Prisoners of Isolation: Solitary Confinement in Canada (Toronto: University of Toronto Press, 1983).

32 Michael Jackson, "Reflections on 40 Years of Advocacy to End the Isolation of Canadian Prisoners," Canadian Journal of Human Rights 4 (2015): 60.

33 Canadian Bill of Rights S.C. 1960, c. 44, s. 2(b).

34 Jackson, "Reflections on 40 Years".
} 
regime that authorizes administrative segregation in federal prisons is constitutionally invalid as inflicting cruel and unusual treatment or punishment contrary to s. 12 of the Canadian Charter of Rights and Freedoms. ${ }^{35}$ They will further argue that the administrative segregation regime violates prisoners' s. 7 right to life, liberty, and security of the person, and the right not to be deprived thereof in accordance with the principles of fundamental justice. They charge that the regime is arbitrary, grossly disproportionate, procedurally unfair, and fails to accommodate the needs of people with disabilities. The claim, ${ }^{36}$ brought by the British Columbia Civil Liberties Association and the John Howard Society of Canada as public interest litigants, will include expert and lay witnesses describing the deep and lasting harms caused by administrative segregation and the extent to which it is unnecessary and ultimately counter-productive to achieving safety and security.

The trial, originally scheduled for January 2017, was adjourned to June 2017, and as parties pursued settlement negotiations. At a time when the harms of solitary confinement are increasingly well documented, and the constitutional law undergirding the claim has developed in the claimants' favour in recent years, the possibility of a settlement raises some concerns. If the parties agree, for example, to hard time limits on the use of administrative segregation (such as thirty-day or fifteen-day limits) or agree to certain new procedures for imposing it, those changes will receive the imprimatur of constitutionality. Consequently, it will be more difficult in future to argue that the whole practice of prisoner isolation is cruel, inhumane, and therefore, unlawful. The history of settled prisoner lawsuits is instructive. In 2013, the Correctional Service of Canada settled a lawsuit brought by BobbyLee Worm, an Indigenous woman who had spent years in solitary confinement pursuant to a policy regime called the Management Protocol, which subjected a small group of "difficult to manage," mostly Indigenous women prisoners to a prolonged regime of segregation that denied them access to prison programs and basic legislative protections. ${ }^{37}$ As part of the settlement, the Management Protocol was formally abolished, but the prolonged solitary confinement of women prisoners persists under new policies and procedures.

While prisoner litigation is still relatively rare in Canada and courts have sometimes taken a "hands-off" deferential approach to judicial review of correctional decision-making, ${ }^{38}$ some significant decisions have been made in favour of prisoners challenging solitary confinement and in favour of meaningful rightsbased judicial review of prison conditions. In the 1980s, the Supreme Court of Canada held in a trilogy of cases that prisoners have certain procedural rights

\footnotetext{
35 Part 1 of the Constitution Act, 1982, being Schedule B to the Canada Act 1982 (UK), 1982, c 11.

36 British Columbia Civil Liberties Association and John Howard Society of Canada v. Canada (Attorney General), Notice of Civil Claim, British Columbia Supreme Court, 19 January 2015, online: https://bccla.org/wp-content/uploads/2015/01/2015-01-19-Notice-of-Civil-Claim1.pdf (the "BCCLA/JHS claim").

37 British Columbia Civil Liberties Association, "Prisoner who spent three-and-a-half years in solitary confinement wins settlement from federal government," online: https://bccla.org/2013/05/ media-province-solitaryconfinement/.

38 Debra Parkes, "A Prisoners' Charter? Reflections on Prisoner Litigation under the Canadian Charter of Rights and Freedoms," UBC Law Review 40 (2007): 629.
} 
when prison officials decide to transfer them to administrative segregation or to high maximum security units, ${ }^{39}$ deciding importantly that prisoners have "residual liberty interests" as members of the general prison population.

More recently, the Supreme Court has strongly affirmed the right of prisoners to seek habeas corpus review in the provincial superior courts of the lawfulness of their conditions of confinement. Habeas corpus is the "great writ of liberty," dating back hundreds of years to the days of the Magna Carta in England, that prohibits and provides a remedy for unlawful detention. In May $v$. Ferndale Institution, ${ }^{40}$ the Court ruled that an involuntary transfer from minimum to medium security was unlawful and repudiated the deferential "hands-off" approach that Canadian courts had often taken in prisoner litigation. ${ }^{41}$ Again in Mission Institution in Khela $^{42}$ the Court stressed, in response to government arguments that sought to limit habeas corpus review, that this remedy was crucial in the prison context where it "is in fact the strongest tool a prisoner has to ensure that the deprivation of his or her liberty is not unlawful." 43 A key feature of the law of habeas corpus that favours its use in the prison context is the burden of proof: once a prisoner can show a deprivation of their residual liberty (i.e., through placement in segregation or through transfer to a higher security institution), the burden shifts to the correctional authorities to prove that the conditions of confinement and the procedure used to place a prisoner in those conditions, are lawful. ${ }^{44}$

While most Canadian prisoners do not have meaningful access to the courts to enforce their rights due to very limited (and, in some provinces, non-existent) legal aid funding for prisoner cases, ${ }^{45}$ we are nevertheless seeing some successful habeas corpus decisions ordering prisoners to be released from solitary confinement. In 2010, a British Columbia judge held that the conditions of solitary confinement experienced by a prisoner awaiting trial for murder amounted to cruel and unusual punishment in violation of s. 12 of the Charter and a writ of habeas corpus was issued. ${ }^{46}$ In this case, counsel was able to put a substantial evidentiary record before the court, including the expert evidence of Craig Haney, a professor of psychology and law at the University of California Santa Cruz, one of the world's

Cardinal and Oswald v. Director of Kent Institution, [1985] 2 SCR 643; $R$ v. Miller, [1985] 2 SCR 613; and Morin v. National Special Handling Unit Review Committee, [1985] 2 SCR 662.

May v. Ferndale Institution [2005] 3 SCR 809.

Ibid., at paras 24-32.

42 Mission Institution in Khela [2014] 1 SCR 502 (ruling that the decision of correctional authorities to transfer Khela to a higher security prison was made without disclosure of relevant information to Khela and was therefore unlawful for violating principles of procedural fairness).

45 In Manitoba, for example, Legal Aid does not provide funding for prisoner rights litigation and therefore such litigation is virtually non-existent, despite news stories highlighting overcrowded prisons and suspicious deaths in custody. See, e.g., Jillian Taylor, "Human rights lawyer calls for public inquiry after 5 inmate deaths," CBC News, 28 October 2016, online: http://www.cbc.ca/ news/canada/manitoba/human-rights-lawyer-public-inquiry-5-inmate-deaths-1.3826977. In rare cases, lawyers from the Public Interest Law Centre in Winnipeg have been able to secure limited funding for test cases. See, e.g., Wiebe v. Bonnefoy, 2015 MBQB 118 (ruling that the transfer of Wiebe from medium to maximum security was done in violation of principles of procedural fairness and issuing the writ of habeas corpus granting Wiebe's return to medium security). 
leading experts on the effects of solitary confinement. Haney visited the Surrey Pretrial Centre, including the segregation unit where Bacon was incarcerated, and concluded that Bacon's conditions of confinement were horrendous. McEwan J. agreed and found those conditions to be cruel and unusual, stating, "The petitioner is kept in physical circumstances that have been condemned internationally. He is locked down 23 hours per day and kept in the conditions Professor Haney described as "horrendous". These conditions would be deplorable in any civilized society, and are certainly unworthy of ours. They reflect a distressing level of neglect. On top of this, the petitioner is only allowed out at random times. He is denied almost all human contact. His treatment by the administration and the guards is highly arbitrary and further accentuates his powerlessness." ${ }^{37}$

Later, McEwan J. added, "The respondent is in breach of s. 12 of the Charter in arbitrarily placing the petitioner in solitary confinement, in failing to appropriately mitigate his circumstances in solitary confinement, and in unlawfully denying him the other rights to which he was entitled, significantly threatening his psychological integrity and well-being. These impositions collectively amount to cruel and unusual treatment." ${ }^{38}$

Justice McEwan was not prepared to find that solitary confinement was per se cruel and unusual punishment, citing a twenty-year-old unsuccessful s. 12 claim by convicted serial murder, Clifford Olson, who had represented himself. ${ }^{49}$ However, McEwan J. went on to suggest that future challenges might be successful: "While there is a growing sense internationally, as well as in Canada, that locking a person down for 23 hours per day is an inappropriate way to treat any human being, the courts remain tethered to the standard of 'gross disproportionality."'50

In 2016, federally sentenced prisoners held in segregation at the Edmonton Institution were ordered released from segregation when they successfully brought an action, self-represented, for habeas corpus. In finding that the decision to place the men in solitary was procedurally unfair and therefore unlawful, ${ }^{51}$ Veit J. had this to say about the relevance of the Mandela Rules:

[94] I conclude that, while the Mandela Rules are not determinative, they encapsulate an international standard in relation to the treatment of prisoners which Canada acknowledges; those rules inform, but do not dictate, the result in a Canadian habeas corpus application.

[95] What we can take from the Mandela Rules is that solitary confinement is a last resort in the treatment of prisoners. Custodial institutions must be zealous in limiting the use of that technique to those situations where the use of solitary confinement is, unfortunately, the only reasonable alternative available to them to manage what is undoubtedly a difficult population. ${ }^{52}$

\footnotetext{
$47 \quad$ Ibid., at para 292.

48 Ibid., at para 353.

$49 \quad R$ v. Olson (1987) 38 CCC (3d) 534 (Ont CA), cited in Bacon, supra, note 46 at para 302.

50 Bacon, supra, note 46 at para 313. For further discussion of Bacon, see Lisa Kerr, "Contesting Expertise in Prison Law," McGill Law Journal 60 (2014): 43, 79-84, and Debra Parkes, "The Punishment Agenda in the Courts," (2014), 67 SCLR (2d) 589 at 607-08.

51 Hamm v. Attorney General of Canada (Edmonton Institution), 2016 ABQB 440.

52 Ibid., at paras 94-95.
} 
At a time of rising awareness about solitary confinement and inhumane prison conditions, section 12 Charter claims seem to be achieving more traction in the courts than they did in the early Charter jurisprudence. ${ }^{53}$ For example, a recent decision of the Ontario Superior Court found that the imposition of lockdowns at Maplehurst Correctional Centre violated the rights of a remand prisoner and an immigration detainee who represented themselves in the habeas corpus action. ${ }^{54}$ Gray J. appointed an experienced human rights lawyer, Barbara Jackman, as amicus curiae given the important and complex issues at stake. The Court ultimately concluded that the many lockdowns imposed due to staff shortages amounted to cruel and unusual punishment, stating "I have little difficulty in concluding that the treatment of the applicants, in their totality, was so excessive as to outrage standards of decency; was disproportionate; and was degrading. Thus, it violated s. 12 of the Charter." 55 The Court took the relatively rare step of awarding damages for the Charter violations: $\$ 60,000$ to Ogiamien and $\$ 25,000$ to Nguyen, rejecting the government's argument that a simple declaration of rights violation would suffice.

In another case involving self-represented prisoner litigants, Gogan v. Nova Scotia (Attorney General), ${ }^{56}$ the Nova Scotia Supreme Court found unlawful the provincial corrections policy of holding federal prisoners awaiting trial on new charges in Nova Scotia in segregation in a provincial jail. The Court was not prepared to take a deferential approach to correctional decision-making that imposed solitary confinement, deeming wholly inadequate the government's stated justification of overcrowding: "It is unreasonable to make prisoners pay for overcrowding, whether it results from fiscal restraint or minimum sentences or both, by making them submit to the agony of solitary confinement. All prisoners are forced to pay for the government's choice of overcrowding by being housed in overcrowded jails and prisons. To compound that with solitary confinement when on remand is unreasonable because it is so unfair." ${ }^{57}$ The habeas corpus application was allowed. ${ }^{58}$

In another strand of cases, sentencing judges are finding that harsh conditions of confinement experienced by people awaiting trial-including lockdowns, overcrowding, violence condoned or perpetrated by staff, and prolonged solitary confinement-amount to cruel and unusual punishment. Judges in these cases are ordering a reduction in sentence as a remedy pursuant to s. 24(1) of the Charter, which empowers courts to order "such remedy as the court considers appropriate and just in the circumstances." In $R v$. Palmantier, ${ }^{59}$ a judge in the Northwest

53 See generally Parkes, "Prisoners' Charter," 659, and Parkes, "Punishment Agenda," supra, note 50, at 605-12.

Ogiamien v. Ontario, 2016 ONSC 3080.

Ibid., at paras 267-68.

Gogan v. Nova Scotia (Attorney General) 2015 NSSC 360.

Ibid., at para 32 .

The reported decision in Gogan does not include discussion of what remedy was ordered as the report ends with the judge saying, "As agreed during the hearing, I will discuss remedy now." I have not been able to find a report of the decision on remedy.

$59 \quad R v$. Palmantier 2014 NWTTC 10. See also R v. Aqqiaruq, 2009 NUCJ (Inhumane conditions experienced during ten days spent in RCMP holding cells violated s. 12. Those conditions included being forced to sleep on a concrete floor, being denied medication, and being provided with a blanket with blood and urine on it. Sentence reduced from four months to one day plus time served.) 
Territories held that Palmantier's pre-trial custody spent in an isolation cell, often without access to basic necessities such as clothing, a shower, a mattress, and bedding, was "inhumane and uncivilized," in violation of s. 12. In a similar vein, in $R v$. Adams, ${ }^{60}$ the judge credited Adams with six years for twenty months of pretrial custody, the conditions of which cumulatively amounted to a violation of s. 12. Those conditions included repeated assaults by other prisoners, the failure of correctional officers to protect Adams, "petty discipline" imposed, and an assault by a correctional officer. ${ }^{61}$

It is important to bear in mind that these cases involving sentence reductions to compensate for unlawful prison conditions remain relatively rare. Punitive legislation enacted during nearly a decade of federal Conservative rule brought in, to name just a few changes, more mandatory minimum sentences, ${ }^{62}$ limited access to early parole, ${ }^{63}$ and-of particular significance to the instant discussion about remedies for inhumane prison conditions-limitations on the ability of sentencing judges to order enhanced credit for pre-trial detention. ${ }^{64}$ Before those changes, judges had exercised discretion in ordering that pre-trial custody served in particularly harsh conditions, including lockdowns, double-bunking, and segregation, could be calculated at a rate of three or four days to one, to reduce the ultimate sentence. ${ }^{65}$ The possibility of judges reducing sentences as a remedy for Charter violations as in Palmantier and other cases remains, but there are few reported decisions making such orders. In addition, increasing the number of mandatory minimum sentences means that there may be fewer instances in which a judge will have room to reduce a sentence to compensate for Charter violations. ${ }^{66}$

The cases highlighted here-including a number brought by prisoners without the assistance of counsel-suggest that at least some judges are receptive to prisoner

$60 \quad R v$. Adams 2016 ABQB 648.

61 But see $R v$. Hopely, [2015] BCCA 499 (denying any enhanced credit beyond 1:1 to a man who had spent all twenty-six months of pre-trial custody in segregation) and $R v$. $C B, 2016$ ONCJ 209 (denying enhanced credit beyond 1:1.5 to a man whose year and a half in pre-trial custody had included more than 150 lockdowns, triple-bunking for seventeen days, and 115 days in segregation, with the Court noting, at para 172, that defence counsel "conceded that the Criminal Code and case law do not permit the Court to grant any credit greater than 1.5:1").

62 See generally Raji Mangat, More than We Can Afford: The Costs of Mandatory Minimum Sentencing (Vancouver: British Columbia Civil Liberties Association, 2014).

63 Abolition of Early Parole Act, SC 2011, c 11, s 10(1), repealing s 125(1) of the Corrections and Conditional Release Act, SC 1992, c 20.

64 Truth in Sentencing Act, SC 2009, c 29, amending Criminal Code, s 719(3)-(3.1). But see $R v$. Summers, 2014 SCC 26 (interpreting s 719(3) which provides as follows: "In determining the sentence to be imposed on a person convicted of an offence, a court may take into account any time spent in custody by the person as a result of the offence but the court shall limit any credit for that time to a maximum of one day for each day spent in custody." The Court held that the lost opportunity for early release and parole during pre-sentence detention can be a circumstance capable of justifying enhanced credit at rate of 1.5:1). See also $R$ v. Safarzadeh-Markhali, [2016] 1 SCR 180 (declaring s 719(3.1), which capped pre-sentence credit at 1:1 in certain circumstances, invalid under the Charter).

65 See, e.g., $R$ v. Permesar, [2003] OJ 5420 (Prov. Ct); $R$ v. Ichikawa, [2004] OJ 5537 (Prov. Ct); $R$ v. Coombs, [2003] AJ 1209 (QB); and R v. Bennett, [1993] OJ 892 (Gen Div).

66 The Supreme Court has left open the door to decreasing a sentence below a mandatory minimum to remedy a Charter violation in "exceptional circumstances": $R$ v. Nasogaluak, [2010] 1 SCR 206 (in which the Court did not find an unjustified near-death beating of the accused by police to be exceptional). There are no reported cases satisfying this high threshold. 
claims, particularly those involving solitary confinement. There have also been settlements reached in human rights claims ${ }^{67}$ and other systemic claims challenging regimes of solitary confinement, ${ }^{68}$ as well as a number of class action lawsuits filed, seeking damages for inhumane conditions, solitary confinement, lockdowns, and the like. ${ }^{69}$ Extensive media coverage of the inhumane conditions experienced by Ashley Smith, Adam Capay, and others forms the backdrop for current prisoner litigation and calls for the abolition of segregation by the Ontario Human Rights Commission, ${ }^{70}$ former Supreme Court Justice and United Nations High Commissioner for Human Rights, Louise Arbour, ${ }^{71}$ and others. At the same time, evidence is mounting that imprisonment is a failed experiment, ${ }^{72}$ yet it is deeply entrenched in Canadian law. It is therefore worth reflecting on the possible relationships between prisoner rights litigation and a broader, anti-carceral social justice strategy.

\section{The Promise and Perils of Prisoner Litigation}

Prisons are closed institutions that are resistant to outside scrutiny and accountability. Despite strong stated commitments to human rights and the rule of law, serious abuses and illegalities occur with alarming frequency in Canadian prisons and jails. Repeated recommendations for systemic change to address discrimination and abuse go unheeded, such as those made annually by the Correctional Investigator. Media coverage and ombuds office reports can shed light on abuses and illegality, and can occasionally prompt government responses, but only courts have the power to enforce rights and require meaningful changes to be made. Louise Arbour remarked pointedly in her 1996 Report of the Commission of Inquiry into Certain Events at the Prison for Women in Kingston that, in Canadian prisons, "[t]he Rule of Law is absent, although rules are everywhere."

67 In 2013, Ontario settled a human rights complaint brought by Christina Jahn, who was living with cancer, addictions, and mental illness when she was incarcerated in solitary confinement for 210 days at the Ottawa-Carleton Detention Centre in 2010-2011. The settlement included a number of public interest remedies including that the Ministry of Community Safety and Correctional Services would keep and publish statistics about the use of segregation: http://www.ohrc.on.ca/en/ segregation-and-mental-health-ontario\%E2\%80\%99s-prisons-jahn-v-ministry-communitysafety-and-correctional.

68 British Columbia Civil Liberties Association, supra, note 36.

69 Brazeau v. Attorney General (Canada), 2016 ONSC 7836 (certifying a class action in relation to solitary confinement). See also Statement of Claim in Lapple et al. v. Ontario, court file CV-16-558633-OOCP (pending certification) regarding lockdowns in Ontario jails: https://kmlaw.ca/cases/ontario-prisonerclass-action/. A class action suit on behalf of federally sentenced prisoners who were held in segregation has also been approved in Quebec: "Quebec class action lawsuit seeks damages for solitary confinement” CTV News, 23 January 2017, online: http://www.ctvnews.ca/canada/quebecclass-action-lawsuit-seeks-damages-for-solitary-confinement-1.3253961.

70 See also the Ontario Human Rights Commission's call for an action plan to abolish segregation in Ontario: http://www.ohrc.on.ca/en/news_centre/end-segregation-says-ontario-human-rightscommission.

71 Catherine Tunney, "Louise Arbour, former Supreme Court justice, calls for end of segregation in prisons," CBC News, 9 July 2016, online: http://www.cbc.ca/news/politics/louise-arboursegregation-inquiry-1.3670487.

72 See generally, Angela Y. Davis, Are Prisons Obsolete? (New York: Seven Stories Press, 2003) and May Schenwar, Locked Down, Locked Out: Why Prison Doesn't Work and How We Can Do Better (Berrett-Koehler Publishing, 2014).

73 The Hon. Louise Arbour, Report of the Commission of Inquiry into Certain Events at the Prison for Women in Kingston (Canada: Public Works and Government Services, 1996), 181. 
concluded that judicial oversight of prisons, and the power of judges to reduce a sentence already in progress to compensate for illegality or serious abuses, is required in the correctional context to enforce compliance with the law. ${ }^{74}$ The BCCLA/JHS claim, seeking a court order that the whole regime of administrative segregation is constitutionally invalid, follows this logic: the Correctional Service of Canada persists in using solitary confinement as a management tool, and it falls to the courts to end this harmful practice.

The American experience with prison litigation concerning solitary confinement is instructive in a number of ways. Reiter suggests that rights litigation may have operated to entrench and legitimize solitary confinement, while tinkering around the edges and "constitutionalizing" it with some limits and procedural protections. ${ }^{75}$ However, there is also evidence that litigation can be part of an anti-carceral agenda, cracking open a window and shedding light on the utter inhumanity of the practice of imprisonment. Jonathan Simon's discussion of Brown v. Plata, ${ }^{76}$ in which the US Supreme Court held that conditions in the California prison system amounted to cruel and unusual punishment, suggests that litigation can be part of the struggle against mass incarceration. ${ }^{77} \mathrm{He}$ opens his recent book, Mass Incarceration on Trial: A Remarkable Court Decision and the Future of Prisons in America, with the words, "Like a biblical flood, the age of mass incarceration is finally ebbing,"78 and goes on to credit the litigation-combined with other activism and reform efforts-with bringing about this change. He says that the "litigation revealed a depth of depravity in California's prisons that most academic critics, including me, had not imagined." ${ }^{\prime 9}$ Simon argues that the court decisions culminating in Brown v. Plata "show the way towards a legal dismantling of mass incarceration." 80

Keramet Reiter and Natalie Pifer suggest that this view was overly optimistic. ${ }^{81}$ They note that Simon's argument that Brown v. Plata facilitated the "dismantling of mass incarceration" is supported by just one statistic: California had reduced its state prison population significantly in the year following Brown. However, during the same period, county jail populations increased by seventeen percent. Reiter and Pifer conclude that "the history and implementation of ... Plata reveal that this litigation has contributed as much to the retrenchment of administrative and political power as to the dismantling of mass incarceration." ${ }^{~} 2$

Writing very recently, Reiter examines two prisoner lawsuits that have had some success in limiting solitary confinement, finding that, in both cases, the lawyers leveraged significant critical investigative reporting and prisoner collective

Ibid., 183.

Reiter, "Most Restrictive," 117-18.

Brown v. Plata 563 U.S. 493.

Jonathan Simon, Mass Incarceration on Trial: A Remarkable Court Decision and the Future of Prisons in America (New York: The New Press, 2014).

Ibid., 1.

Ibid., 2.

Ibid., 3 .

81 Keramet Reiter and Natalie Pifer, "Brown v. Plata," Oxford Handbooks Online (Oxford: Oxford University Press, 2015).

82 Ibid., 2. 
activism, with these elements contributing to the results. ${ }^{83}$ She argues for multimethod approaches to reform litigation, while also highlighting lessons from the history of the use of solitary in the US, in particular that the practice has been remarkably persistent despite calls for reform or abolition dating back more than a century; that prisons are opaque and unaccountable; and that the use of solitary is subject to administrative discretion, to which courts tend to be deferential. ${ }^{84}$

A crucial point that is often not part of prisoner litigation or other prison reform efforts is an understanding that the persistence of solitary confinement (or other forms of isolation and inhumane treatment) is rooted in carceral logics. Imprisonment itself creates its own logic and imperative for the use of solitary. When people are put in cages, many of them will not respond well to that environment. They will act out. They will harm themselves or others. Consequently, they are put in smaller cages (segregation cells) and they do even less well, but they are contained. The fundamental carceral logic of punishing and caging goes unchallenged. As Allegra McLeod notes, "despite its more apparent horrors, solitary confinement is simply an extension of the logic and basic structure of prison-backed punishment-punitive isolation and surveillance-to the disciplinary regime of the prison itself." 85 She goes on to say that once the initial logic of imprisonmentstripping people of their capacity to move of their own volition, to interact with others, and to exercise basic control over their own lives-is accepted as legitimate, solitary confinement simply applies that logic inside prison walls. ${ }^{86}$

Herein lies the problem of prisoner rights litigation that is not accompanied by a critique of carceral logics: if, for example, we seek only to abolish those smaller cages (solitary confinement) but leave intact the logic of caging people in the first place, then some other correctional tool or practice will take the place of solitary and we will soon be fighting that. Drawing on the American experience, Montfort, Hannah-Moffat, and Hunter describe how conditions of solitary confinement have historically been renamed and recalibrated when faced with exposure and challenge. ${ }^{87}$ In Canada, we saw this in the aftermath of the Management Protocol settlement, discussed earlier. With this in mind, the next section considers some of the ways that a prison abolitionist ethic might productively inform lawyering efforts to alleviate some of the harms of incarceration and to contribute to broader, anti-carceral social movements.

\section{A Prison Abolitionist Lawyering Ethic}

There is a crucial place in anti-carceral social movements for litigation with and on behalf of prisoners to obtain release from inhumane conditions of confinement or to seek damages or sentence reductions to compensate for suffering and illegality.

83 Keramet Reiter, "Lessons and Liabilities in Litigating Solitary Confinement," Connecticut Law Review 48 (2016): 167.

84 Ibid.

85 Allegra McLeod, “Prison Abolition and Grounded Justice," UCLA Law Review 62 (2015): 1179.

86 Ibid., 1180.

87 Kelly Struthers Montford, Kelly Hannah-Moffatt, and Alexandra Hunter, “Too wicked to die': The enduring legacy of humane reforms to solitary confinement," unpublished manuscript on file with author. 
It is vital that prisoners have allies on the outside who can advocate knowledgeably, strategically, and in their interests. But prisoner rights advocacy may also have the effect of entrenching correctional logics in constitutionalized form, thereby undermining broader critiques of the carceral state and efforts to dismantle it. Fortunately, examples exist of the role that litigation can play in critical social movements, including prison abolitionist projects. This final section offers some preliminary thoughts on the contours and possibilities of a prison abolitionist lawyering ethic, identifying some examples of successful incorporation of abolitionist logic in legal work, and engaging with the oft-cited distinction between reformist and non-reformist or abolitionist advocacy. ${ }^{88}$ Allegra McLeod argues for a prison abolitionist ethic and framework to ground the research and teaching of criminal law and policy. ${ }^{89}$ She suggests that "when we are forced to confront what prisons do, we are compelled to consider the ideological work prison performs. We come to recognize prison, then, as more than 'an abstract site into which undesirables are de-posited, relieving us of the responsibility of thinking about the real issues afflicting those communities from which prisoners are drawn in such disproportionate numbers." 90 McLeod's analysis rejects the idea that an abolitionist approach is inconsistent with working through and with the law to expose and seek redress for the real harms caused by incarceration. The notion of an abolitionist ethic, framework, or lens through which lawyers and scholars might engage with the criminal law and incarceration opens up new conversations and possibilities for doing things differently, in the classroom and in the courtroom.

Examples of lawyers incorporating a prison abolitionist ethic into their work can be found in a number of jurisdictions. In the United States, the National Lawyers' Guild, which is described on its website as "the nation's oldest and largest progressive bar association," adopted a resolution in favour of prison abolition in December 2015. ${ }^{91}$ The Abolitionist Law Centre (ALC) is a law firm working in Pennsylvania which states on its website that, "[w] orking with prisoners in defense of human rights has led us to the realization that the prison system-and, in particular, its reliance on solitary confinement-is part of a larger system that operates according to a logic of violence and intimidation. Solitary confinement is used to terrorize the prisoner population.... The ALC works with prisoners, their families, and our allies in order to further efforts to abolish this form of torture."

Benjamin Fleury-Steiner ${ }^{93}$ has highlighted the influential role that feminist prison abolitionist ethics and approaches played in the US prisoners' rights movement in the late 1960s, led by imprisoned Black women such as Angela Davis and Assata Shakur. These activists were sceptical of litigation as a reliable tool for social

\footnotetext{
88 Thomas Mathieson, The Politics of Abolition Revisited (Abingdon: Routledge, 2015), citing the 1974 version at 223-25.

89 McLeod.

90 Ibid., 1211, citing Angela Y. Davis, Are Prisons Obsolete? (New York: Seven Story Press, 2003$), 15$.

91 https://www.nlg.org/nlg-adopts-resolution-supporting-prison-abolition/.

92 https://abolitionistlawcenter.org/docket-areas/solitary-confinement/.

93 Benjamin Fleury-Steiner, "Different Approaches Need to be Taken in Different Settings - Situating Activist Prison Lawyering: The Struggle for HIV-Positive Prisoners' Rights" Studies in Law, Politics, and Society 38 (2006): 5.
} 
change, but the movements they formed began to use litigation in strategic ways, particularly in the years of the Warren Court, which decided a number of important prisoners' rights cases. ${ }^{94}$ Again in the 1980s and 1990s, when, as Fleury-Steiner notes, the US Supreme Court and Congress "were chiseling away at prisoner rights protections, a grassroots prisoner rights movement was underway,"95 and the catalyst for that movement was Ellen Barry and her organization, Legal Services for Prisoners with Children (LSPC), which remains a strong prisoner rights group today. Recently, for example, LSPC was co-counsel in Ashker, ${ }^{96}$ where a historic settlement was reached on behalf of California prisoners held in solitary confinement. The focus of LSPC's advocacy was around issues affecting incarcerated mothers and their children. That early group, which involved Angela Davis and others, formed a committee of former prisoners, academics, activists, and families of prisoners to organize a conference, Critical Resistance: Beyond the Prison Industrial Complex, which drew over 3,000 people in 1998. That abolitionist movement prioritized non-state centered action, rather than litigation. However, activist litigation has continued to play a role in the Critical Resistance (CR) movement.

Abolitionist prison lawyers in the United States who are part of the CR movement and who advance rights litigation on behalf of HIV-positive prisoners carefully balance their broader movement objectives with providing legal services to their clients and, in effect, being active participants in a system that legitimizes incarceration as a penal practice. ${ }^{97}$ For example, Christina Dyer and Cassandra Shaylor co-direct an organization in Oakland, California, called Justice Now, which is the first teaching law clinic focused solely on women prisoners and which employs many former prisoners who do popular education, training, art, and community organizing to raise awareness of the inhumanity of incarceration. Dyer said in an interview with Fleury-Steiner, "I have very little confidence in litigation affecting social change.... [it] has only really created band-aid reforms at best." Notwithstanding that deep scepticism of litigation, Dyer noted that her organization does do legal work for prisoners, particularly seeking compassionate release for dying prisoners. However, when they do so, they combine their legal efforts with a media campaign describing the broader systemic issues and highlighting the way that prisons are a form of state violence. ${ }^{98}$

Bree Carlton has described how a prison abolitionist ethic, specifically a feminist anti-carceral approach, has been integral to social justice campaigns in Victoria, Australia, around the imprisonment of women. ${ }^{99}$ While acknowledging that well-meaning prison reform efforts often contribute to prison expansion ${ }^{100}$

Ibid.

Ibid., 7.

Center for Constitutional Rights.

Fleury-Steiner, 10-11.

Christina Dyer, in Fleury-Steiner, 13.

Bree Carlton, "Penal reform, anti-carceral feminist campaigns and the politics of change in women's prisons, Victoria, Australia," Punishment and Society 0(0) (2016): 1.

100 Ibid., 7, drawing on Dean Spade, Normal Life: Critical Trans Politics and the Limits of Law (Cambridge MA: South End Press, 2011). 
and the legitimation of carceral logics, ${ }^{101}$ Carlton "explores how anti-carceral feminists have used reform as a resistance strategy within Victorian anti-discrimination campaigns in the 1980s and 1990s. Placed in historical context, these campaigns demonstrate the transformative possibilities and risks associated with the necessary navigation and pursuit of reformist strategies that is fundamental to a politics and practice of abolition." 102

A number of the feminist campaigners in Carlton's study are lawyers. Strategic litigation and the strategic deployment of anti-discrimination claims and analysis were infused with an anti-carceral ethic and a deep commitment and connection to the women inside the prison. For example, the campaigners literally formed a ring around the prison and camped out there in solidarity with the women. They spoke out regularly and forcefully about the violence of incarceration and cultivated public support for the women inside, while advocating for their rights.

Returning to Canada, the activism and advocacy of Kim Pate, formerly the Executive Director of the Canadian Association of Elizabeth Fry Societies (CAEFS) and now a Member of the Senate, provides an instructive example of a prison abolitionist ethic ${ }^{103}$ guiding the deployment of rights and other legal strategies. Throughout her more than two decades with CAEFS, Pate has formed broadbased coalitions that have called wide attention to the violence and harms of incarceration, particularly for women, all the while naming the injustices as violations of rights and demanding accountability, compensation, and decarceration as remedies. Pate is a non-practicing lawyer who often describes herself as a "recovering lawyer" because she sees herself primarily as an activist and advocate, working in solidarity with marginalized and imprisoned women. In fact, Pate is a brilliant and creative legal mind who has developed new legal strategies and built coalitions that have influenced the critical positions taken by many institutions and organizations in favour of the decarceration of women. She has engaged strategically with the law, working with lawyers and in coalition with other social justice groups ${ }^{104}$ to take positions in habeas corpus applications, ${ }^{105}$ coroner's inquiries, ${ }^{106}$

101 See e.g., Kelly Hannah-Moffat, Punishment in Disguise: Penal Governance and Federal Women's Imprisonment in Canada (Toronto: University of Toronto Press, 2001) and Stephanie Hayman, Imprisoning Our Sisters: The New Federal Women's Prisons in Canada (Montreal: McGill-Queens University Press, 2006) on unintended consequences of feminist prison reform efforts. Carlton, 1.

103 See generally “Prison Abolition in Canada," Upping the Anti 4 (2006), online: http://uppingtheanti.org/ journal/article/04-prison-abolition-in-canada/ (profiling prison abolitionists Peter Collins, Julia Sudbury, Kim Pate, and Patricia Monture).

104 Gayle Horii, Debra Parkes, and Kim Pate, “Are Women's Rights Worth the Paper They're Written On? Collaborating to Enforce the Human Rights of Criminalized Women," in Criminalizing Women: Gender and (In)justice in Neo-Liberal Times, ed. Elizabeth Comack and Gillian Balfour (Halifax: Fernwood Press, 2006), 302.

105 Beaudry et al. v. Canadian Association of Elizabeth Fry Societies et al., 1997 CanLII 514 (ONCA) involved a group of women prisoners challenging a proposed transfer from the then Prison for Women to the Regional Treatment Centre in Kinston Penitentiary (a men's prison). The action was settled and the transfer was cancelled.

106 Chief Coroner of Ontario, Inquest Touching the Death of Ashley Smith: Jury Verdict and Recommendations, December 2013, online: http://www.caefs.ca/wp-content/uploads/2014/01/A.S.Inquest-Jury-Verdict-and-Recommendations1.pdf (in which CAEFS successfully advocated for a verdict of homicide in the death of Ashley Smith and urged recommendations abolishing segregation for women and providing mental health resources for criminalized women in the community). 
and human rights proceedings, ${ }^{107}$ and to seek anti-carceral remedies such as the decarceration of women with mental health needs (rather than advocating for those services to be delivered in a prison setting). Pate insists on seeing prisoners as rights holders and on using legal mechanisms to seek their release or to lessen and remedy the harms they experience in prison. She is critical of litigation or law reform efforts that are reformist in nature, and Pate has taught a number of prison law seminars at Canadian law schools, educating a new generation of lawyers to utilize a range of legal mechanisms within a prison abolitionist framework.

Collectively, these example drawn from the United States, Australia, and Canada suggest that a prison abolitionist lawyering ethic is both possible and useful to broader social movement organizing. This exploratory look at prison abolitionist lawyering is not meant to be definitive or exhaustive of this work, but in these examples, we see some common themes: a rejection of carceral logics; a focus on strategies to get people out of prison rather than on making prison better; and a deep commitment to coalition-building and connections to abolitionist and other critical social movements. The current moment, in which public attention is being paid to the inhumanity of solitary confinement, presents an opportunity to consider how a prison abolitionist lawyering ethic might inform or change the nature of prisoner rights litigation to end this harmful practice.

One element of an abolitionist ethic is to develop legal arguments in a way that rejects carceral logics, rather than legitimizes them. The carceral logics that produce solitary confinement in Canadian prisons include, for example, the assumptions that prison can be rehabilitative, that placement in segregation (or some other more restrictive prison environment) is necessary for those people who do not adjust to a prison environment, and that (many) prisoners are dangerous and in need of caging. It is unclear whether the evidence and arguments in the BCCLA/ JHS solitary confinement trial will involve challenging these and other carceral logics. However, the focus of the claim on "prolonged and indefinite segregation" and the need for limits and oversight suggest a reformist focus.

Abolitionist thought has long distinguished between reformist and abolitionist projects, ${ }^{108}$ although, as discussed above, abolitionists have engaged in campaigns, advocacy and litigation that seeks to alleviate some of the pains and harms of incarceration. A reformist approach that does not disrupt or challenge the carceral logics underlying the practice of solitary confinement can contribute to the expansion and proliferation of carceral sites, as we have seen in response to a recent review of the practice of segregation in Ontario, led by the former federal Correctional Investigator, Howard Sapers. ${ }^{109}$ The decision to build two new and improved prisons, with expanded capacity, has been the primary response of the Ontario government to the report which also called for hard time limits on the use

107 Canadian Human Rights Commission, Protecting Their Rights: A Systemic Review of Human Rights in Corrections for Federally Sentenced Women, December 2003.

108 Mathieson.

109 Independent Review of Ontario Corrections, Segregation in Ontario (Queen's Printer for Ontario, 2017), online: http://www.mcscs.jus.gov.on.ca/sites/default/files/content/mcscs/docs/IROC\%20 Segregation\%20Report\%20ENGLISH\%20FINAL_0.pdf. 
of segregation and independent oversight of the practice. At the same time, there are growing Canadian campaigns, such as the NOPE (No on Prison Expansion) initiative calling for a national moratorium on prison expansion, ${ }^{110}$ with which prisoner rights lawyers might productively engage.

The element of seeking non-carceral remedies, rather than improving prisons, is also challenging for lawyers to navigate. The suggestion is not that lawyers should sacrifice the immediate well-being of their clients by refusing to argue for improved conditions of confinement (including medical treatment or transfer to a lower security prison); but rather, that a prison abolitionist lawyering ethic will necessarily involve critical reflection about the impact of the claims they pursue and the arguments they make on behalf of prisoners. For example, enforcing a prisoner's right to quality mental health care need not always mean arguing that the care should be delivered in prison. At a conference on solitary confinement held in 2013, Tona Mills, a woman who had spent years in segregation in Canadian prisons, spoke about how advocates on her behalf were successful in convincing a judge to order that she be placed in a community mental health facility because prison itself was a risk factor for her. ${ }^{111}$ Of course, it is not always possible to secure the release of a client, but in the hands of a lawyer who is "thinking outside the bars," the range of legal options and remedies may be expanded. It would not have been obvious to most lawyers that such an order would even be possible for a sentenced prisoner.

It is also relatively rare for lawyers to work in connection with abolitionist and other community organizations, but the work cited above is promising. ${ }^{112}$ Creative advocacy seeking non-carceral remedies can be informed by, and accountable to, grassroots campaigns that may seek to free individual prisoners as part of a broader abolitionist agenda. For example, the contemporary \#FreeBresha and \#FreeMarissa, participatory defence campaigns in the United States have been organized to free Bresha Meadows, a fourteen-year-old Black teenager, and Marissa Alexandar, a Black mother of three. Both Meadows and Alexandar were criminalized and imprisoned for defending themselves against abusers when the state had failed to protect them. Mariame Kaba says of participatory defence campaigns that "these short-term strategies need to be placed within a longer-term vision for justice rather than as a substitute for that vision." 113 She goes on to urge that advocates be mindful of the limitations and dangers of some of these strategies and to consider how they might reframe this struggle to address systemic racism and criminalization more broadly. For lawyers who seek to do this work, the challenge is to locate short-term strategies to free individuals within a larger abolitionist vision. In this way, advocates are accountable to, and mindful of, the way that their work supports (or not) an abolitionist future.

110 Criminalization and Punishment Education Project, "No On Prison Expansion/\#NOPE Initiative," online: http://cp-ep.org/no-on-prison-expansion-nope-initiative/.

111 Debra Parkes, "Ending the Isolation: Introduction to the Special Volume on Human Rights and Solitary Confinement," Canadian Journal of Human Rights 4 (2015): vii-ix.

112 See, e.g., Carlton, on the broad coalitions built by anti-carceral feminist campaigners in Victoria, Australia.

113 Mariame Kaba, “Free Us All," The New Inquiry, 8 May 2017, online: https://thenewinquiry.com/ free-us-all/. 
Thinking about the possibilities of strategically deploying rights language and advocacy in the context of "movement defence" work (such as lawyering in defence of protestors at the 2010 G20 summit in Toronto), Irina Cerić suggests that critical scholars and lawyers can be part of counter-hegemonic struggles and social movements. ${ }^{114}$ She offers "a preliminary explication of movement lawyers and activist scholars as organic intellectuals, agents in what Antonio Gramsci described as 'the war of position' in his conceptualization of revolutionary social change." ${ }^{115}$ In this exploratory work, Cerić sketches the contours of reflective critical lawyering that sees law as both refuge and grievance and that advances analyses of, for example, the "criminalization of dissent" that go beyond liberal constitutional frames. This kind of critical engagement with movement lawyering has much to offer prisoner rights lawyers who seek to build and support anti-carceral social movements.

There is no question that these elements of a prison abolitionist lawyering ethicrejecting carceral logics, seeking non-carceral remedies, and working in coalition-are not an easy fit for many lawyers. Punishment and incarceration are deeply embedded principles in Canadian law, and rights strategies tend to work within, rather than push the limits of, those boundaries. Beginning in law school, with few exceptions, lawyers are inculcated into a culture that views incarceration as entrenched and legitimate social policy. The criminal law treats the purported benefits (public safety, deterrence, denunciation, rehabilitation) as self-evident, even in the face of substantial evidence of the institution's failure to deliver on these promises. ${ }^{116}$ In this culture, the role of prisoner rights lawyers is to make prisons more humane and rights-respecting. An abolitionist ethic therefore entails a cultural shift for lawyers interested in doing this work. Allegra McLeod argues that, "Abolition as an ethical and institutional framework-as an aspirational horizon for reform-is not unduly or merely utopian, but orients critical thought and reformist efforts toward meaningful and just legal, ethical, and institutional transformation to which we might commit ourselves." 117 A nascent culture of prison abolitionist lawyering has the potential to be part of that transformation.

Debra Parkes

Chair in Feminist Legal Studies

Peter A. Allard School of Law

University of British Columbia

parkes@allard.ubc.ca

\footnotetext{
114 Irina Cerić, “Towards Praxis: Movement Lawyers and Scholars as Organic Intellectuals," unpublished manuscript on file with author.

115 Ibid., citing Antonio Gramsci, Selections from the Prison Notebooks (New York: International Publishers, 1971), 6.

116 See e.g., David Scott, "Why Prison? Posing the Question," in Why Prison? ed. David Scott (Cambridge: Cambridge University Press, 2013), 10-16.

117 McLeod, 1239.
} 